\title{
A PRÓSTATA E SUA INTERFERÊNCIA NA SEXUALIDADE MASCULINA
}

\author{
Antônio Pereira Bueno Filhol
}

\section{Introdução}

Na medicina, o termo hiperplasia é usado para definir o aumento benigno da glândula prostática, que não costuma ocorrer antes dos 45 anos e, embora sua etiopatogenia não esteja completamente elucidada, tem-se como certo que seu aparecimento e sua manutenção dependem de fatores hormonais. Ela só ocorre quando os testículos estão presentes, não existindo em homens castrados antes da puberdade, e pode sofrer involução parcial, após a castração . A próstata é a maior glândula sexual acessória masculina e, sabidamente, tem uma função exócrina, cuja secreção responde por 15\% do volume total ejaculado. Funcionalmente, tem atividade relevante na ejaculação, ocluindo a luz da uretra e propiciando que o líquido seminal siga de forma anterógrada até o meato uretral e na continência urinária masculina, juntamente com o esfincter da uretra posterior e o colo vesical, atuando no controle urinário. 0 peso normal da próstata é de aproximadamente dezoito gramas e ela engloba a uretra em sua porção mais próxima à bexiga.

\footnotetext{
'Médico do Hospital Municipal da Piedade (R.J) e do Centro de Investigação Urológica Mestre em Sexologia pela Universidade Gama Filho Titular da Sociedade Brasileira de Urologia

E-mail:drantoniobueno@click21.com.broudrantoniobueno@ig..com.br
} 
Atualmente, dispomos de um bom arsenal medicamentoso para tratar a hiperplasia prostática, como o inibidor da cinco alfa redutase (a finasterida) e os alfa-bloqueadores. No entanto, em virtude da demora dos pacientes para procurar este tratamento, o que em geral ocorre quando os sintomas estão muito exacerbados, faz com que a melhor opção terapêutica acabe sendo o tratamento cirúrgico. A cirurgia é indicada em função dos sintomas obstrutivos ou do aparecimento de complicações, como a retenção urinária aguda, ou, a litiase (cálculo vesical).

\section{Manifestações clínicas da hiperplasia prostática benigna}

Os portadores de hiperplasia prostática apresentam manifestações clínicas que podem ser divididas, para efeito didático, em dois grupos:

1) manifestações obstrutivas: aparecem em 70 a $80 \%$ dos pacientes com hiperplasia prostática benigna e resultam do efeito mecânico da glândula prostática sobre a luz uretral.

2) manifestações irritativas: surgem devido à reação do músculo detrussor a obstrução uretral, com sintomas devido à instabilidade vesical. Estas manifestações estão presentes em 50 a 70\% dos pacientes com hiperplasia prostática benigna e nem sempre desaparecem após tratamento cirúrgico. Em geral, os sintomas relacionados à necessidade de intervenção cirúrgica são: a dificuldade para começar o ato da micção, fluxo urinário reduzido e incontinência urinária paradoxal (que é quando o paciente urina por transbordamento, de tão repleta que está a bexiga) .

A disfunção erétil (DE) é reconhecidamente elevada na faixa etária em que se encontram os pacientes portadores de hiperplasia prostática benigna. Keil, Sutherland, Knapp et al. (1992) demonstraram que 30\% dos homens, entre 66 e 69 anos, e 60\% dos que estão acima de 80 anos, apresentam disfunção erétil; os portadores de hiperplasia benigna da próstata têm grandes probabilidades de apresentarem $\mathrm{DE}$, em função da faixa etária em que se encontram, independentemente de terem ou não doença prostática. Além de ser notório que a sintomatologia decorrente 
da hiperplasia prostática influi na qualidade de vida do homem e, por conseqüência, também possa prejudicar seu desempenho sexual.

A nictúria (aumento da freqüência urinária noturna) impede o repouso, determinando dificuldades na concentração e na memória, deixando o paciente exausto para suas atividades cotidianas. Além do mais, a freqüência miccional noturna exagerada interrompe o sono, impedindo a ocorrência da fase de movimentos rápidos dos olhos (REM), levando à repercussão na qualidade da ereção. A urgência, ou incontinência urinária, produz, além do desconforto, o constrangimento social, retraindo sobremaneira o indivíduo, com marcada repercussão em sua qualidade de vida. A ardência miccional e a dor aumentam a liberação de catecolaminas que, por conseqüência, inibem o relaxamento da musculatura lisa cavernosa, fatos que podem comprometer a ereção. $\mathrm{Na}$ faixa etária em que se encontram esses pacientes, podem ocorrer fenômenos depressivos, como a perda da esposa, o falecimento de algum filho, a limitação da capacidade física, a queda da receita financeira. Eventos que, somados à ansiedade e aos efeitos colaterais das medicações, muitas vezes usadas por eles, influem decisivamente para que a DE se instale. Constantemente, muitos pacientes utilizam-se do quadro clínico da hiperplasia prostática benigna para justificar a presença de uma disfunção erétil que, na realidade, pode advir de causas diversas.

\section{Alterações do desempenho sexual causada pelo tratamento cirúrgico}

Avaliaremos aqui as alterações produzidas pelas duas técnicas cirúrgicas mais comuns, que são a prostatectomia supra-púbica e a ressecção transuretral.

a) Prostatectomia suprapúbica: a prevalência de D.E., após esta técnica cirúrgica, oscila em torno de 10\%; a ejaculação retrógrada atinge $91 \%$ dos pacientes operados e a diminuição da sensação orgásmica ocorre em 21\%, segundo dados do I Encontro de Consenso Nacional sobre HBP, realizado em 1996. De acordo com Comfort (1978), dependendo do 
crescimento do lobo mediano e seu avanço para dentro do colo vesical, durante a retirada cirúrgica deste, o colo vesical fica aberto, fazendo com que a loja prostática esteja em comunicação direta com a bexiga, o que, em muitos pacientes, pode ser detectado através de exames radiológicos contrastados. Como o colo vesical é o sítio anatômico do esfincter vesical interno, uma estrutura que exerce tanto uma função genital (durante a ejaculação normalmente ele é fechado, prevenindo assim a entrada do sêmen dentro da bexiga e facilitando a sua expulsão através da uretra), quanto uma função urinária (ele é uma das estruturas responsáveis pela continência urinária), sob controle do sistema nervoso simpático, caso o colo vesical permaneça aberto, após a prostatectomia, o sêmen é expelido para dentro da bexiga, ao invés de seguir através da uretra até o meio externo. A este fenômeno denominamos ejaculação retrógrada.

b) Ressecção transuretral da próstata: a ressecção transuretral da próstata é hoje considerada o tratamento padrão e com melhores resultados para a obstrução urinária decorrente da hiperplasia prostática benigna, porém, é associada com piora da função sexual. A grande maioria dos homens submetidos a essa intervenção cirúrgica fica com diminuição considerável do volume ejaculado e muitos cursam com ausência total da ejaculação, pela uretra, pois esta passa a ser retrógrada (para dentro da bexiga). Isso de deve à retirada do parênquima glandular, levando diretamente à diminuição da produção do líquido seminal, à obstrução cicatricial dos ductos ejaculadores, o que prejudica a emissão seminal e provoca a diminuição do mecanismo de oclusão do colo vesical. Embora a grande maioria dos pacientes refira que a sensação prazerosa do orgasmo não seja alterada pela falta da ejaculação, essa conseqüência previsivel deve ser extensamente conversada com o paciente, antes da cirurgia. Caso contrário, o descobrimento do orgasmo a seco (sem ejaculação de líquido seminal pelo pênis), no pós-operatório, pode ocasionar graves danos psicológicos, pois o homem pode considerar-se mutilado, agravando ou desencadeando uma disfunção erétil. Segundo o I Encontro de Consenso Nacional sobre HBP (1996), a incidência de impotência sexual após RTUP varia entre 0 e 40\%. 
Em dissertação de Mestrado em Sexologia da Universidade Gama Filho, (Bueno Filho, 2000) observamos, que o medo mais freqüentemente relatado pelos homens estudados, no que se refere às cirurgias prostáticas, foi o de tornarem-se "impotentes sexualmente". Em função do descrito anteriormente, torna-se indispensável que todos os pacientes portadores de hiperplasia prostática benigna sejam questionados e instruídos em relação ao desempenho sexual, antes de instituir-se qualquer terapêutica. Essa avaliação incluiu a freqüência das relações, a libido, a qualidade da rigidez peniana, ejaculação (volume), orgasmo e grau de satisfação com a relação sexual, além de esclarecimentos relativos a cirurgia prostática e suas possiveis conseqüências na vida sexual do paciente. 